\title{
STRATEGI PUBLIC RELATIONS HOTEL DALAM MEMBENTUK CITRA OBJEK WISATA
}

\author{
Poppy Ruliana dan Ririh Dwiantari \\ Sekretaris Program Pascasarjana Magister Ilmu Komunikasi \\ STIKOM InterStudi, Jl. Wijaya II No. 62 Kebayoran Baru - Jakarta Selatan \\ Telp (021) 7262111, Fax. (021) 72796080 \\ Email: poppyruliana@yahoo.co.id
}

\begin{abstract}
The purpose of this study is to determine the communication strategy of marketing through public relations approach between hotel and community. The model used in this study is a Public Relations strategy planning model of Cutlip, Center \& Broom (2009). Method used in this research is descriptive qualitative approach. Data were collected by doing participatory observation, in-depth interviews, documentary studies and triangulation. Data wrere analyzed through the stages of data reduction, data presentation, conclusion and verification. Result shows that the PR strategy planning model proposed by Cutlip, Center \& Broom can support this research.
\end{abstract}

Keywords: Public Relations, Image

\begin{abstract}
Abstrak
Tujuan penelitian ini untuk mengetahui strategi komunikasi pemasaran melalui pendekatan public relations antara hotel dengan masyarakat. Permasalahan dalam penelitian ini adalah bagaimana strategi public relations sebagai salah satu strategi dari komunikasi pemasaran terpadu dapat membentuk citra produk camping park Hotel X. Model yang digunakan dalam penelitian ini adalah model perencanaan strategi Public Relations dari Cutlip, Center \& Broom (2009) metode yang digunakan dalam penelitian ini adalah deskriptif dengan pendekatan kualitatif. Teknik pengumpulan data dilakukan dengan observasi partisipasi, wawancara mendalam, studi dokumentasi dan triangulasi. Teknik analisis data melalui tahap reduksi data, tahap penyajian data, tahap penarikan kesimpulan dan verifikasi data, Hasil penelitian menunjukkan bahwa model perencanaan strategi PR yang dikemukakan oleh Cutlip, Center \& Broom dapat mendukung penelitian ini.
\end{abstract}

Kata Kunci : Public Relations, Citra

\section{Pendahuluan}

Pariwisata memainkan peran penting dalam kegiatan pemasaran baik taktis dan strategis yang terintegrasi dengan komunikasi pemasaran (blogspot. com/2012/11/makalah industri pariwisata). Industri pariwisata memiliki sektor tersendiri seperti hotel dan penginapan, restoran, perusahaan, tujuan wisata, dan layanan transportasi. Keberadaan masingmasing komponen pariwisata tersebut harus dapat diterima oleh masyarakat sekitar pada umumnya dan tamutamu serta mereka yang menggunakan fasilitas-fasilitas pariwisata tersebut untuk bermacam-macam keperluan pada khususnya. Jadi hotel merupakan salah satu komponen dari pariwisata dan merupakan bagian integral dari usaha pariwisata yang menurut Keputusan Departemen Pariwisata, Pos dan Telekomunikasi melalui Jendral Pariwisata (dalam Sulastiyono: 2006:11), disebutkan sebagai suatu bentuk bangunan, lambang, perusahaan atau badan usaha akomodasiyang menyediakan pelayanan jasa menginap, menyediakan makanan dan minuman serta fasilitas jasa lainnya dimana semua pelayanan itu diperuntukkan bagi masyarakat umum, baik mereka yang bermalam di hotel tersebut maupun mereka yang hanya menggunakan fasilitas tertentu yang dimiliki hotel itu. Pelayanan-pelayanan 
penunjang lain seperti :tempat - tempat rekreasi, fasilitas olah raga, fasilitas dobi (laundry)

Sejalan dengan banyaknya jumlah hotel yang saat ini tersebar di beberapa daerah tujuan wisata, interaksi antara pengguna jasa perhotelan semakin meningkat, karenanya dirasakan perlu adanya suatu strategi komunikasi pemasaran melalui pendekatan public relations antara hotel dengan masyarakat pengguna, dalam hal ini adalah para pengunjung yang kita kenal dengan istilah wisatawan, baik wisatawan domestic maupun wisatawan internasional melalui penyampaian informasi yang benar, akurat dan dapat dipercaya dan juga menjaga kualitas pelayanan yang baik terhadap para wisatawan. (http.blogspot. com/makalah-pariwisata, feb2013:18.30).

Mengacu pada uraian di atas, Hotel $X$ adalah perusahaan yang bergerak dalam bidang jasa,merupakan bagian dari komponen industri pariwasata yang menjadi kebanggaan masyarakat Jawa Barat, khususnya Kabupaten Subang yang terletak di kaki Gunung Tangkuban Perahu. Hotel $X$ memiliki selling point tersendiri karena memiliki ciri khas objek wisata, yaitu sumber daya air panas yang memiliki khasiat untuk menyembuhkan berbagai penyakit yang dapat dijadikan sebagai destinasi pariwisata. Informasi yang diperoleh dari ManagerOperasional, bahwa kandungan air panas di Sari Ater merupakan terbaik kedua se Asia Pasifik setelah Yugoslavia, yang pada waktu itu dibuktikan oleh Doctor Rafael dari Yugoslavia.

Hotel X membangun inovasi produk baru yaitu Camping Park sebagai sarana pendukung hotel yang ditawarkan kepada pengunjung atau wisatawan, baik wisatawan nusantara maupun wisatawan mancanegara. Produk ini memiliki daya tarik tersendiri karena wisatawan dapat menyatu dengan alam dan mengenal lingkungan alam sekitar secara langsung sehingga dapat merasakan kenyamanan udara pegunungan yang jauh dari polusi udara. Di samping itu, produk camping park ini menurut Direktur Operasional Hotel $X$ belum banyak ditawarkan oleh hotel lain yang sejenis, tetapi kalaupun ada, berbeda dalam pengemasan (packaging) produknya atau pun pemasarannya. Selanjutnya, dari hasil wawancara yang dilakukan peneliti dengan Manager Public Relations Sari Ater Hotel $\mathcal{E}$ Resort pada tanggal 25 Februari 2014 diperoleh informasi bahwa:

"Program camping park ini baru berjalan sekitar 2 tahun yang didirikan pada tahun 2012 danmemiliki tiga tipe tenda yaitu Rusa, Landak dan Musang, masing-masing tenda memiliki kapasitas dan pemandangan (view) yang berbeda baik dari segi harga dan fasilitas yang ditawarkan kepada konsumen atau pelanggan dan diberikan discount khusus pada bulan-bulan tertentu". (Hasil Wawancara, 25 Februari 2014)

Untukmencapai tujuan yang diharapkan yaitu memperoleh citra produk, pihak perusahaan melalui Departemen Sales \& Marketing menawarkan paket program camping park yang sifatnya kontekstual dan merupakan suatu strategi komunikasi pemasaran yang terencana dan sistematis. Salah satu strategi yang dilakukan dalam melaksanakan komunikasi pemasaran adalah melalui public relations. Strategi ini digunakan menurut pendapat peneliti, karena tujuan dari sales $\mathcal{E}$ marketing berbeda dengan Public Relations dalam proses komunikasi pemasarannya. Marketing biasanya memiliki tujuan bagaimana memperoleh keuntungan atau profit yang sebesar-besarnya, sedangkan public Relationsadalah bagaimana memperoleh citra produk dimata pelanggan/konsumen, namun dalam pelaksanaannya, melakukan kerjasama (koordinasi) untuk mencapai keuntungan dan sekaligus memperoleh positioning yaitu citra produk. (Cutlip \& Center, 2006:230). 
Tabel 1. Pengunjung Hotel X pada Tahun 2013

\begin{tabular}{|c|c|c|c|c|c|}
\hline \multirow{2}{*}{ Bulan } & \multicolumn{3}{|c|}{ Tipe Tenda } & \multirow{2}{*}{$\begin{array}{l}\text { Jumlah } \\
\text { Orang }\end{array}$} & \multirow{2}{*}{$\begin{array}{c}\text { Jumlah } \\
\text { Tenda }\end{array}$} \\
\hline & Rusa & Landak & Musang & & \\
\hline Agustus & 32 & 38 & - & 286 & 70 \\
\hline September & 21 & 18 & 19 & 236 & 58 \\
\hline Oktober & 39 & 20 & - & 236 & 59 \\
\hline Nopember & 39 & 30 & 10 & 497 & 79 \\
\hline Desember & 40 & 20 & 10 & 500 & 70 \\
\hline
\end{tabular}

Dari hasil observasi partisipasi diperoleh informasi dari Manager Public Relations dan Departemen Rekreasi Hotel $X$ bahwajumlah pengunjung yang tertarik menginap di Camping Parkmengalami peningkatan, hal ini dapat dilihat dalam tabel jumlah pengunjung empat bulan terakhir tahun 2013.

Tabel 1. memperlihatkan jumlah pengunjung yang cukup meningkat tetapi belum signifikan dan belum menunjukkan posisi produk yang diharapkan oleh perusahaan Hotel $X$ tetapi untuk produk baru camping park kenyataannya cukup banyak mendapat perhatian dan diminati oleh para pengunjung atau wisatawan nusantara, seperti Surabaya, Jakarta, Kalimantan Selatan dan wisatawan mancanegara, seperti Polandia, Saudi Arabia, Malaysia dan Korea untuk menginap di camping park. Namun demikian, perlu diperhatikan juga kualitas pelayanan yang diberikan pada para pelanggan yang menginap karena dari hasil observasi pada lokasi camping park banyak para tamu yang mengeluh karena pelayanan yang lama pada saat memesan makanan dan minumanatau pun ketika meminta handuk atau sandal walaupun penjagaannya cukup baik, di samping itu, jarak tempuh menuju lokasi camping park cukup jauh dan jalannya rusak.

Dari sudut pandang strategi komunikasi pemasaran, Public Relations (PR) dapat berperan penting dalam mengatasi permasalahan tersebut karena kalau tidak segera diatasi akan menjatuhkan citra dan reputasi perusahaan yang sudah terbentuk. Oleh karena itu pihak public relations Hotel $\mathrm{X}$ harus menyusun suatu strategi melalui perencanaan dan pemrograman kerja PR dan metode serta teknik komunikasi persuasi yang berbeda sehingga dapat mempengaruhi wisatawan untuk berkunjung dan datang kembali ke objek wisata Hotel $\mathrm{X}$, khususnya camping park.

Peran public relations tidak hanya menarik pengunjung tetapi juga untuk membuat mereka senang setelah mereka tiba (Wilcox, Ault, Agee dan Cameron, 2000). Hal ini sangat penting untuk menciptakan persepsi positif pengunjung dan perasaan tentang tujuan wisata, karena keberhasilan di bidang perjalanan dan industri pariwisata saling tergantung antara satu dengan lainnya.

Public Relations mampu melakukan persepsi untuk mengubah sikap dan perbuatan masyarakat secara langsung maupun tidak langsung. Oleh karena itu, aktivitas promosi yang dilakukan secara besar-besaran harus juga didukung oleh kegiatan public relations yang tepat sasaran dan berkelanjutan. Hal ini karena peran dominan PR dalam membentuk citra daerah tujuan wisata, yang tidak bisa dilakukan secara utuh oleh program promosi adalah bagaimana mengkondisikan informasi yang disampaikan mampu menembus barikade stereotype citra yang telah terbentuk pada tiap individu (Wisesa, 2005:208).

Berdasarkan pada permasalahan sebagaimana yang telah diuraikan di atas, maka peneliti merasa tertarik untuk melakukan penelitan tentang "Strategi 
Public Relations Dalam Membangun Posisi Dan Citra Produk Camping Park di Sari Ater HotelEResortKabupaten Subang, Jawa Barat."

Berdasarkan permasalahan tersebut di atas, maka permasalahan dalam penelitian ini adalah sebagai berikut: 1) Bagaimana strategi PublicRelations membangun posisi dan citra produk Camping Park di Hotel X, 2) Bagaimana strategi perencanaan program yang dilakukan Public Relations dapat membangun posisi dan citra produk Camping Park di Hotel X, 3) Bagaimana strategi komunikasi yang dilakukan Public Relations dapat membangun posisi dan citra produk Camping Park di Hotel $X$, dan 4) Bagaimana evaluasi program yang dilakukan Public Relations dapat membangun posisi dan citra produk Camping Park di Hotel X?

Komunikasi pemasaran merupakan aspek penting dalam keseluruhan misi pemasaran serta penentu suksesnya pemasaran. Komunikasi pemasaran dapat dipahami dengan menguraikan dua unsur pokoknya yaitu komunikasi dan pemasaran. Komunikasi pemasaran adalah proses penyebaran informasi tentangperusahaan dan apa yang hendak ditawarkannya (Offering) pada pasar sasaran. Perannya sangat vital mengingat peran komunikasi dalam memfasilitasi hubungan saling menguntungkan antara perusahaan dengan pembeli prospektif. Berkat perkembangan ilmu pemasaran, tujuan komunikasi kini tak lagi terbatas untuk mendorong pemberian pertama, namun juga memastikan kemungkinan terjadinya pembelian berulang dan pembeli tersebut menjadi pelanggan yang loyal. (Sulaksana,2003:230)

Peran komunikasi dalam pemasaran sangat penting karena itu komunikasi harus dipahami pengertiannya terlebih dahulu. Komunikasi adalah proses dimana pemikiran dan pemahaman disampaikan antar individu, atau antar organisasi dengan individu (Effendy, 2002). Pemasaran adalah sekumpulan kegiatan dimana perusahaan dan organisasi lainnya mentransfer nilainilai (pertukaran) antara mereka dengan pelanggannya (Sulaksana, 2003:23). Sedangkan komunikasi pemasaran mempresentasikan gabungan semua unsur dalam bauran pemasaran merek yang memfasilitasi terjadinya pertukaran dengan menciptakan suatu arti yang disebarluaskan kepada pelanggan atau kliennya. Komunikasi pemasaran merupakan usaha untuk menyampaikan pesan kepada publik terutama konsumen sasaran mengenai keberadaan produk dipasar. (Sulaksana, 2003:24).

Konsep yang secara umum sering digunakan untuk menyampaikan pesan adalah apa yang disebut bauran promosi atau bauran pemasaran. Di dalam bauran pemasaran ini biasanya sering digunakan berbagai jenis promosi. Terdapat lima jenis promosi yang biasa disebut bauran pemasaran seperti yang dijelaskan diatas, yaitu penjualan tatap muka, humas, promosi penjualan, publisitas serta pemasaran langsung (Sulaksana, 2003). Komunikasi pemasaran memegang peranan yang sangat penting bagi perusahaan karena tanpa komunikasi konsumen maupun masyarakat secara keseluruhan tidak akan mengetahui keberadaan produk di pasar. Komunikasi pemasaran juga secara berhati-hati dan penuh perhitungan dalam menyusun rencana komunikasi perusahaanan. Penentuan siapa saja yang menjadi sasaran komunikasi akan sangat menentukan keberhasilan komunikasi, dengan penentuan sasaran yang tepat, proses komunikasi akan berjalan efektif dan efisien.

Model komunikasi pemasaran yang biasa dikembangkan pada umumnya tidak jauh dengan proses komunikasi 
dalam ilmu komunikasi. Model komunikasi pemasaran meliputi sender atau disebut juga sumber (source). Seperti gambar dibawah ini.

Pertama kali pesan komunikasi datang dari sumber. Dalam pemasaran sumber berarti pihak yang mengirim pesan pemasaran kepada konsumen. Pihak yang mengirim pesan tentu saja perusahaan. Proses selanjutnya yaitu perusahaan menentukan bagaimana pesan itu disusun agar bisa dipahami dan direspons secara positif oleh penerima dalam hal ini konsumen. Pada proses tersebut ditentukan pula jenis komunikasi apa yang akan digunakan. Apakah pesan akan disampaikan melalui iklan, personal selling, promosi penjualan, Public Relations (PR) atau pemasaran langsung. Proses enconding ini juga disebut sebagai proses menerjemahkan tujuan-tujuan komunikasi ke dalam bentuk-bentuk pesan yang akan dikirimkan kepada penerima.

Proses yang berikutnya yaitu adalah menyampaikan pesan melalui media. Jika pesan dirancang dalam bentuk iklan, maka pesan harus disampaikan dalam bentuk media cetak atau media elektronik. Pesan yang disampaikan dalam media cetak akan berbeda bentuk dan strukturnya dengan pesan yang disampaikan dalam media elektronik. Pesan dalam media cetak biasanya bersifat detail dan menjelaskan karakteristik

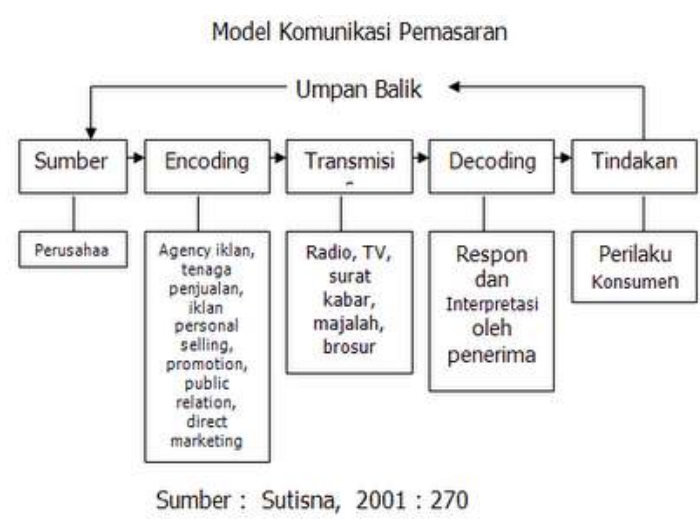

Bagan 1. Model Komunikasi Pemasaran produk secara lengkap. Sedangkan pesan yang akan disampaikan dalam media elektronik seperti radio dan televisi tidak boleh secara detail menerangkan produk karena akan sangat memakan biaya. Proses penyampaian pesan melalui media ini disebut sebagai proses transmisi.

Pesan yang disampaikan melalui media akan ditangkap oleh penerima. Ketika pesan diterima, penerima akan memberikan respon terhadap pesan yang disampaikan. Respon yang diberikan bisa positif, negatif atau netral. Respon positif tentu saja adalah respon yang diharapkan oleh pengirim pesan. Respon positif identik dengan terjadinya keserasian antara harapan pengirim pesan dengan tanggapan penerima pesan.

Dengan perkataan lain, pesan yang dirancang direspon sesuai dengan keinginan perancang pesan. Kesesuaian antara harapan pengirim dengan tanggapan penerima inilah yang diharapkan terjadi, karena hal ini akan mempengaruhi perilaku konsumen secara positif. Hal yang tidak diharapkan terjadi adalah respon negatif atau netral dari konsumen (penerima pesan), respon negatif ini terjadi karena tidak terjadinya keserasian antara harapan pengirim pesan dengan respon dilakukan oleh penerima. Pengirim mengharapkan A, konsumen mengharapkan $B$, jadi ada ketidaksesuaian antara harapan pengirim dengan tanggapan konsumen. Proses memberikan respons dan menginterprestasikan pesan yang diterima disebut sebagai proses decoding. Proses decoding berarti penerima pesan memberi interprestasi atas pesan yang diterima.

Proses decoding ini akan dilanjutkan dengan tindakan konsumen sebagai penerima pesan, jika pesan yang sampai diterima secara positif, maka hal ini akan memberikan pengaruh positif pada sikap dan perilaku konsumen. Sikap positif konsumen terhadap suatu 
produk akan mendorong konsumen untuk melakukan tindakan pembelian, karena dibatasi oleh kemampuan daya beli. Sedangkan sikap negatif terhadap produk akan menghalangi konsumen untuk melakukan tindakan pembelian. Janganlah sikap negatif, sikap positif pun tidak semuanya diakhiri dengan pembelian, apalagi jika sesorang mempunyai sikap negatif, pasti akan sangat menghalangi tindakan pembelian. Oleh karena itu, pembentukkan sikap positif terhadap produk sangat penting dilakukan oleh perusahaan.

Proses terakhir, umpan balik atas pesan yang dikirimkan. Perusahaan mengevaluasi apakah pesan yang disampaikan sesuai dengan harapan, artinya mendapat respon dan tindakan yang positif dari konsumen atau justru pesan tidak sampai secara efektif. Pengukuran efektifitas pesan adalah tingkat penjualan produk yang ditawarkan ke pasar. Pesan melalui iklan disebut berhasil atau efektif jika tingkat penjualan produk setelah proses penyampaian pesan meningkat secara signifikan. Sebaliknya pesan yang disampaikan tidak efektif jika setelah pesan disampaikan penjualan produk tidak meningkat, atau justru turun. Indikator penjualan ini seharusnya menjadi sinyal awal bagi perusahaan untuk melakukan penelitian atas pesan yang sampaikan ke konsumen. (Sutisna, 2006: 270-272)

Dalam penelitian ini difokuskan pada public relations sebagai salah satu strategi dalam melakukan komunikasi pemasaran untuk memperoleh positioning dan citra produk. Salah satu alasan mengapa memilih PR sebagai strategi komunikasi pemasaran karena peran PR semakin penting diakui keberadaannya oleh perusahaan dalam mengelola hubungan penting dengan masyarakat atau public yang dijadikan sasaran
Cutlip, Center dan Broom (2006) mendefinisikan public relations is the management function which evaluates public attitudes, identifies the policies and procedures of an individual or an organization with the public interest, and plans and executes a programm of action and communication to earn public understanding and acceptance. Definisi lain tentang PR dikemukakan oleh seorang pakar manajemen hotel William Scholz (dalam A. Yoeti, 2000) mendefinisikan PR sebagai berikut: Public Relations has been described as: the planned effort to influence opinion through socially responsible performance based on mutually satisfactory two way communications.

Scholz (dalam A. Yoeti, 2000 dan Ruliana, 2014) mengemukakan lebih lanjut bahwa PR tidak lain adalah usaha pembinaan hubungan baik dengan tetangga, atau menjadi seorang penduduk kota yang baik atau menjadi seorang eksekutif yang baik, menjadi idola orang banyak. Kata Scholz, 90\% dari kegiatan itu adalah memelihara hubungan baik (good relations), sedang 10\% lagi adalah memperkenalkan aktivitas bisnis yang digeluti.

Definisi di atas menggambarkan bagaimana seorang PR harus dapat menciptakan komunikasi yang sifatnya dua arah, yaitu ke dalam membina hubungan dengan public internal (manajemen) dan keluar membina hubungan dengan publik eksternal yaitu publik yang dijadikan sasaran. Dalam kaitannya dengan hal ini, William Scholz ( dalam A.Yoeti, 2000: 12) memberikan contoh bagaimana PR dapat menjaga hubungan baik dengan semua lapisan masyarakat, sbb: a) Public relations is smiling at people. b) Public relations is asking a father how his children are. c) Public relations is keeping your place of business attractiv. d) Public relations is having a staff of neat courteous employees. e) Public relations remembering a man's name when he comes 
Tabel 2. Proses Perencanaan Strategis Public Relations

PROSES PERENCANAAN STRATEGIS PR

\begin{tabular}{|c|c|}
\hline Proses Empat Langkah & $\begin{array}{c}\text { Langkah Perencanaan Strategis } \\
\text { Dan Outline Program }\end{array}$ \\
\hline A. Mendefinisikan Masalah & $\begin{array}{l}\text { 1. Problem, perhatian, atau } \\
\text { peluang apa yang sedang } \\
\text { terjadi }\end{array}$ \\
\hline B. Perencanaan dan pemograman & $\begin{array}{l}\text { 3. Tujuan program } \\
\text { 4. Publik sasaran } \\
\text { 5. Sasaran apa yang harus } \\
\text { dicapai }\end{array}$ \\
\hline $\begin{array}{l}\text { C. Mengambil tindakan dan } \\
\text { komunikasi }\end{array}$ & $\begin{array}{l}\text { 6. Strategi aksi } \\
\text { 7. Strategi komunikasi apa isi } \\
\text { pesan yang harus } \\
\text { disampaikan }\end{array}$ \\
\hline D. Mengevaluasi program & $\begin{array}{l}\text { 8. Rencana implementasi } \\
\text { 9. Rencana evaluasi } \\
\text { 10. Umpan balik dan } \\
\text { penyesuaian program }\end{array}$ \\
\hline
\end{tabular}

into your establishment after not having been there for some time, and f) Public relations is shoveling snow off the front sidewalk

Harus diketahui bahwa PR bukan hanya sekedar "menjual senyum". PR menghendaki lebih dari itu, ia memerlukan strategi agar perusahaan disenangi dan dipercaya oleh pihak - pihak yang hendak berhubungan dengan perusahaan. PR lebih merupakan suatu fungsi manajemen yang melakukan komunikasi untuk menciptakan pemahaman, saling pengertian, dan kepercayaan yang berbeda - beda tentang PR itu sendiri, apakah PR itu diperlukan atau tidak.

Fungsi utama PR dalam melaksanakan komunikasi pemasaran seperti yang dikemukakan oleh Kotler (dalam Sulaksana, 2003:124-125) adalah sebagai berikut: a) Hubungan dengan pers dalam menyajikan berita dan informasi tentang perusahaan dengan sepositif mungkin. b) Publisitas produk tertentu. c) Komunikasi korporat: meningkatkan kesepahaman organisasi melalui komunikasi internal dan eksternal. d) Lobi: menjalin hubungan erat dengan para penentu kebijakan dan kalangan legislative untuk mendukung atau justru menggagalkan peraturan dan undang-undang tertentu. e) Konseling: memberi saran manajemen tentang isuisu public dan bagaimana perusahaan harus menyikapinya serta tentang citra perusahaan

Sedangkan peran PR menurut Dozier (dalam Ruliana, 2014) dibagi dalam empat kategori, yaitu: a) Expert Prescriber -praktisi PR membantu manajemen dengan pengalaman dan keterampilan mereka untuk mencari solusi bagi penyelesaian masalah public relationship yang dihadapi organisasi. b) Communication facilitator - membantu manajemen dengan menciptakan kesempatan untuk "mendengar" apa kata publik dan menciptakan peluang agar publik mendengar apa yang diharapkan manajemen. c) Problem solving process 
facilitator - praktisi PR membantu kerja manajemen melalui memuaskan bagi masalah PR. d) Communication technician menyediakan layanan teknis komunikasi untuk organisasi sedangkan keputusan untuk teknis komunikasi yang baru harus dijalankan oleh orang atau bagian lain dalam organisasi. Dalam peranan ini praktisi PR sering juga disebut sebagai "journalist in residence"

Scott M. Cutlip \& Allen H. Center (2006), menyatakan bahwa proses perencanaan program kerja melalui "proses empat tahapan atau langkahlangkah pokok" yang menjadi landasan acuan untuk pelaksanaan program kerja Public relations yang dikemukakan oleh Cutlip, Center dan Broom (2006:409) menggambarkan model 4 langkah perencanaan strategi PR.

Tabel 2 mendeskripsikan proses atau suatu tahapan atau langkah-langkah bagaimana seorang PR melaksanakan peran dan fungsinya dalam menangani isu-isu yang berkembang.

Tahap pertama adalah mendefinisikan masalah (Defining Public Relations Problems). Dalam tahap ini, PR melakukan observasi atau pengamatan mengenai permasalahan-permasalahan yang menyangkut pemberitaan/isuisu yang mengemuka di media massa maupun di media cetak maupun di media sosial, seperti facebook, twitter sebagai tahap awal pengumpulan data dan mengidentifikasi permasalahan yang mengemuka yang sudah menjadi sikap, opini publik dan perilaku publik.

Tahap kedua, Perencanaan dan Pemograman (Planning and Programming) yang dapat dilakukan oleh PR adalah membuat planning yang merupakan perincian secara teratur dan berurutan tentang langkah-langkah yang akan dilaksanakan untuk mencapai tujuan tertentu. Programming adalah susunan acara, yaitu perincian waktu atau timing secara teratur dan menurut urutan tertentu tentang pelaksanaan langkah demi langkah sesuai dengan apa yang telah ditetapkan dalam planning. Selain, sebuah perencanaan dan program yang sedemikian matang, tapi tak ideal apabila tidak ada unsure publikasi, maka PR harus cerdas mengetahui media apa yang akan digunakan dalam menunjang kegiatan PR tersebut.

Cutlip, Centre dan Broom (dalam Ruliana, 2014:180-186) mengklasifikasikan media dalam 3 kategori, yang dapat dipakai untuk internal public juga eksternal publik yaitu the printed word, the spoken word dan the image. The printed word bisa dilakukan melalui majalah organisasi, brosur, naskah pidato. Kemudian spoken word bisa dilakukan dalam bentuk konfrensi pers, press interview atau meeting, kemudian the image bisa menggunakan media elektronil, media cetak dan media sosial bisa dalam bentuk iklan politik, publikasi politik partai demokrat dan lain sebagainya.

Tahap ketiga, seorang PR harus melakukan mengambil tindakan dan komunikasi (taking action dan communicating) dalam tahap ini Cutlip, Centre dan Broom (2006: 408-409), mengemukakan ada 3 hal yang harus diperhatikan, yakni ; (1) The Action Component Of Strategy ( strategi aksi), dalam hal ini PR harus dapat melakukan tindakan yang sifatnya "acting responsively and responsibly", dalam arti mau mendengar keinginan public dan bertanggung jawab terhadap public yang diwakilinya sehubungan dengan segala kegiatan yang dilakukan. (2)The Communication Component Of Strategy (Strategi komponen komunikasi) PR harus konsentrasi pada pengkomunikasian, tentu saja harus mempertimbangkan seluruh komponen komunikasi yang dilaksanakan mulai pada saat menggunakan media, menggunakan sumber media, membawa komunikan atau 
yang menjadi sasaran komunikasi ke arah yang diinginkan, memodifikasi pesan yang baik, dapat menggiring opini, sikap dan perilaku publik. (3) Implementing the strategy (implementasi strategi PR). Ada 7-Cs PR Communication yang harus diperhatikan oleh PR dalam melaksanakan strategi komunikasi, yaitu : 1) Credibility; dimulai dengan sumber komunikasi yang dianggap kompeten, 2) Context; pesan yang disampaikan harus sesuai sengan realita dan lingkungan dimana komunikasi politik itu dilancarkan dan tidak kontradiksi dengan sasaran sehingga mau berpartisipasi dengan program, 3) Content; bahwa pesan politik yang disampaikan adalah yang dapat dimengerti oleh audience yang menerimanya, 4) Clarity; pesan yang disampaikan haruslah menggunakan term-term yang sederhana, kata-kata yang digunakan harus mempunyai arti yang sama baik kedua belah pihak, 5) Continuity dan Consistency; bahwa pesan komunikasi itu diharapkan berkelanjutan dan konsisten dari waktu ke waktu sehingga publik menjadi semakin yakin dan inherent dengan program kita, 6) Channels; pemilihan media yang tepat dan dapat menjangkau sasaran, 7) Capability of the audience; perlu diperhatikan juga kapasitas sasaran dalam menterjemahan pesan-pesan yang disampaikan sumber komunikasi.

Tahap terakhir adalah Mengevaluasi Program (Evaluating The Program), tahap ini dilakukan, pertama, untuk Mengevaluasi dan mengukur keberhasilan kegiatan yang telah dilaksanakan. Metode pengumpulan pendapat (opinion poll) dan uji sikap (test attitude) menjadi metode atau teknik yang digunakan PR dalam upaya mencapai tujuan yang sudah ditentukan oleh organisasi.

Setiap tahap dari proses kerja PR di atas, sama pentingnya bagi terlaksananya suatu program PR yang efektif. Sayangnya banyak di antara praktisi PR yang kurang menyadari akan hal tersebut sehingga dalam menentukan dan melaksanakan program mereka seringkali mengabaikan tahap-tahap di atas. Tahap yang paling sering diabaikan adalah penelitian, perencanaan dan evaluasi. Sebaliknya, banyak di antara mereka yang terlalu banyak memfokuskan pekerjaannya pada publisitas, yang sebenarnya akan secara otomatis muncul apabila program PR dirancang berdasarkan penelitian, perencanaan dan evaluasi yang serius.

Katz dalam Soemirat dan Ardianto (2004) mengatakan bahwa citra adalah cara bagaimana pihak lain memandang sebuah perusahaan, seseorang, suatu komite, atau suatu aktivitas. Frank Jefkins dalam buku Public Relations (2004:20-23), sebagai "kesan, gambaran, atau impresi yang tepat (sesuai dengan kenyataan) atas sosok keberadaan berbagai kebijakan. Sukatendel (dalam Soemirat dan Ardianto, 2002:120) menyatakan bahwa : citra adalah kesan, perasaan, gambaran diri publik terhadap perusahaan, kesan yang dengan sengaja diciptakan dari suatu obyek, orang, atau organisasi Jadi ungkap Sukatendel, citra itu dengan sengaja perlu diciptakan agar bernilai positif. Citra itu sendiri merupakan salah satu aset terpenting dari suatu perusahaan atau organisasi. Istilah lain adalah favourable opinion.

PR adalah salah satu metode komunikasi untuk menciptakan citra positif dari mitra organisasi atas dasar menghormati kepentingan bersama. Kesan pertama dari definisi tersebut adalah sebagai berikut: 1) Komunikasi adalah ilmu. PR adalah bagian dari ilmu komunikasi ilmu yang sedang tumbuh dan mulai digandrungi. PR cukup ilmiah untuk dipelajari. 2) Citra adalah tujuan yang hendak dicapai oleh suatu organisasi / perusahaan /departemen. 3) Mitra memberi kesan saling memperhatikan. 
Inilah model masyarakat masa depan sehingga PR dituntut untuk berwawasan luas. 4) Kepentingan bersama adalah esensi dari kegiatan PR, jelas dan menggambarkan dua pihak (two way communication).

Jefkins (2003) menyebutkan beberapa jenis citra (image). Berikut ini lima jenis citra yang dikemukakan, yakni; (1) Citra bayangan (mirror image). Citra ini melekat pada orang dalam atau anggota-anggota organisasi biasanya adalah pemimpinnya mengenai anggapan pihak luar tentang organisasinya. (2) Citra yang berlaku (current image). Adalah suatu citra atau pandangan yang dianut oleh pihakpihak luar mengenai suatu organisasi. (3) Citra yang diharapkan (wish image). Adalah suatu citra yang diinginkan oleh pihak manajemen. (4) Citra perusahaan (corporate image). Adalah citra dari suatu organisasi secara keseluruhan, jadi bukan sekedar citra atas produk dan pelayanannya. (5) Citra majemuk (multiple image). Banyaknya jumlah pegawai (individu), cabang atau perwakilan dari sebuah perusahaan atau organisasi dapat memunculkan suatu citra yang belum tentu sama dengan organisasi atau perusahaan tersebut secara keseluruhan.

Jenis - jenis citra tersebut di atas tentunya tergantung pada organisasi sesuai dengan tujuan yang hendak dicapai dan efektivitas PR di dalam pembentukan citra (nyata, cermin dan aneka ragam) organisasi, erat kaitannya dengan kemampuan (tingkat dasar dan lanjut) pemimpin dalam menyelesaikan tugas organisasinya, baik secara individual maupun tim yang dipengaruhi oleh praktek berorganisasi (job design, reward system, komunikasi dan pengambilan keputusan) dan manajemen waktu/ perubahan dalam mengelola sumberdaya (materi, modal dan SDM) untuk mencapai tujuan yang efisien dan efektif, yaitu mencakup penyampaian perintah, informasi, berita dan laporan, serta menjalin hubungan dengan orang. Hal ini tentunya erat dengan penguasaan identitas diri yang mencakup aspek fisik, personil, kultur, hubungan organisasi dengan pihak pengguna, respons dan mentalitas pengguna (Hubeis, 2001).

\section{Metode Penelitian}

Dalam penelitian ini, peneliti menggunakan pendekatan kualitatif. yang dimaksud dengan pendekatan kualitatif adalah suatu pendekatan dalam melakukan penelitian yang beroriantasi pada gejalagejala yang bersifat alamiah karena orientasinya demikian, maka sifatnya naturalistik dan mendasar atau bersifat kealamiahan serta tidak bisa dilakukan di laboratorium melainkan harus terjun di lapangan.Oleh sebab itu, penelitian semacam ini disebut dengan field study. (Nazir, 1986:159). Penelitian kualitatif adalah penelitian yang menghasilkan data deskriptif mengenai kata-kata lisan maupun tertulis, dan tingkah laku yang dapat diamati dari orang-orang yang diteliti (Taylor dan Bogdan, 1984:5). Sehubungan dengan masalah penelitian ini, maka peneliti mempunyai rencana kerja atau pedoman pelaksanaan penelitian dengan menggunakan pendekatan kualitatif, di mana yang dikumpulkan berupa pendapat, tanggapan, informasi, konsepkonsep dan keterangan yang berbentuk uraian dalam mengungkapkan masalah. Jadi yang dimaksud dengan pendekatan kualitatif adalah prosedur penelitian yang menghasilkan penelitian data deskriptif berupa kata-kata tertulis atau lisan tentang orang-orang, perilaku yang dapat diamati sehingga menemukan kebenaran yang dapat diterima oleh akal sehat manusia.

Teknik pengumpulan data dalam penelitian deskriptif kualitatif dilakukan melalui beberapa tahap, yaitu : (Sugiyono: 2008) pertama, Observasi Partisipasi, tahap kedua, Wawancara Mendalam (in-depth interview). Wawancara merupakan alat re- 
cheking atau pembuktian terhadap informasi atauketeranganyangdiperolehsebelumnya. Informan kunci dalam penelitian ini adalah Direktur Operasional Hotel X, Manager Sales \& Marketing Hotel X, Manager HRM Sari Ater Hotel Resort dan Manager Public Relations Hotel X. Alat komunikasi yang digunakan untuk melakukan wawancara adalah sebagai berikut, Tape recorder, Kamera, Note book, Alat tulis. Tahap ketiga, dokumentasi dimana sejumlah besar fakta dan data tersimpan dalam bahan yang berbentuk dokumentasi. Sebagian besar data yang tersedia adalah berbentuk suratsurat, catatan harian, cenderamata, laporan, artefak, foto, dan sebagainya. Sifat utama data ini tak terbatas pada ruang dan waktu sehingga memberi peluang kepada peneliti untuk mengetahui hal-hal yang pernah terjadi di waktu silam. Secara detail bahan dokumenter terbagi beberapa macam, yaitu otobiografi, surat-surat pribadi, buku atau catatan harian, memorial, klipping, dokumen, data di server dan flashdisk, data tersimpan di website, dan lain-lain. Teknik Analisis data penelitian kualitatif menurut Miles dan Huberman ada tiga tahap, yaitu : (a). Tahap reduksi data (b). Tahap penyajian data (c). Tahap penarikan kesimpulan dan verifikasi data.

\section{Hasil Penelitian dan Pembahasan}

Dalam membahas hasil penelitian, penulis mencoba mengaplikasikannya ke dalam model strategi PR tersebut. Ada pun pembahasannya sebagai berikut:

\section{Mendefinisikan Masalah}

Permasalahan yang muncul didirikannya Camping Park oleh pihak Hotel $X$ adalah makin bertambahnya jumlah pengunjung wisatawan, baik wisatawan local, nusantara maupun wisatawan asing sehingga mengakibatkan kurangnya kamar untuk menginap. Hal ini sesuai dengan yang dikemukakan oleh Ottro Haris Samallo seorang Manager Operasional Hotel $X$ mengemukakan

\section{bahwa}

"Salah satu yang melatarbelakangi dibentuknya camping park karena makin bertambahnya pengunjung yang datang ke Hotel $X$ sehingga mengakibatkan kurangnya kamar untuk menginap. Dasar yang ke 2 bahwa pengunjung yang datang merasa bosan sehingga mengharapkan sesuatu yang berbeda.Konsep menyatu dengan alam dan lebih condong ke back to nature juga menjadi ide dibentuknya camping park (Wawancara, 17, Oktober, 2014).

Berdasarkan permasalahan tersebut, pihak manajemen Hotel $\mathrm{X}$ melalui manager PR melakukan survey dan observasi lokasi ke kompetitor yang sudah membuat program perkemahan untuk ditawarkan ke konsumen, seperti di Rancamaya Sukabumi dan Taman Safary di Puncak Kabupaten Bogor. Hal ini dikemukakan oleh PR Manager melalui wawancara yang dilakukan tanggal 7 Juni 2014 mengatakan bahwa

“Sebelum dibentuknya camping park, pihak manajemen melakukan riset terlebih dahulu, dengan melakukan studi banding ke beberapa tempat guna mencari deferensiasi produk dengan yang lain. Disamping juga untuk inovasi produk dari Sari Ater."

Juga dikemukakan oleh Hendra Wibawa seorang Assisten Director of Sales Marketing melalui wawancara tanggal 8 Juni 2014 mengatakan bahwa;

"Sebelum dibentuknya camping park, langkah awal yang dilakukan adalah menyusun terlebih dahulu market segmennya. Siapa yang akan dituju dan mau dibawa kemana sasaran marketnya. Ada pun konsep dari camping park adalah konsep kembali ke alam dan konsep petualangan juga menjadi bagian yang menarik yang ditawarkan produk camping park. Konsep ini dibangun berdasarkan masukan dari pengunjung yang datang ke Sari Ater, dimana pihak front office menawarkan produk camping park kepada mereka. Dan juga karena mereka bosan dengan suasana bising di perkotaan yang membuat mereka datang kembali ke Sari Ater" 
Pendapat dari informan tersebut di atas, bahwa sebelum dibangunnya program camping park terlebih dahulu melakukan penelitian dalam bentuk survey melalui observasi dengan cara melakukan studi banding ke beberapa hotel jenis resort yang memiliki ciri produk yang sama, yaitu produk perkemahan (camping) yang bernuansa alam. Tujuannya adalah untuk memperoleh informasi-informasi atau data, berupa cirri produk yang sama dari para pesaing, kemudina dari data yang dipeoleh tersebut, kemudian dari pahak Hotel X membuat suatu produk yang sama jenisnya tetapi berbeda dalam desain nya termasuk tematik dari produk tersebut adalah family adventure camping park tersebut yang berbeda dengan pesaing. Langkah selanjutnya melakukan survey opini ke lingkungan masyarakat sekitar hotel dan juga meminta pendapat pemerintah kabupaten setempat untuk memperoleh dukungan di bangunnya produk camping park, untuk menghindari permasalahan

Selanjutnya melakukan survey lokasi untuk membangun camping park di area Hotel X dan ditemukanlah lokasi yang cocok yaitu di area Hotel $X$, tepatnya di Desa Nagrak, bukit palasari, Kecamatan Ciater, Kabupaten Subang. Seperti hasil wawancara yang dilakukan dengan manajer operasional, bapak Otto Harris Samalo pada tanggal 1 Oktober di ruang kerja Manajer Operasional Hotel X, berikut ini :

"Lokasi camping park berada di sisi aliran sungai jernih di kaki bukit pinus Palasari. Di aliran sungai tersebut juga terdapat sebuah air terjun kecil. Di sekitar tempat camping terdapat hamparan ladang para petani sayuran, sedangkan di sebelah selatan Anda tampak gunung Tangkuban Parahu menjulang. Karena masih berada di dataran tinggi, anda bisa melihat hamparan dataran rendah yang luas di sebelah utara, seperti yang tampak dalam gambar di bawah ini adalah lokasi di mana camping park berdiri."

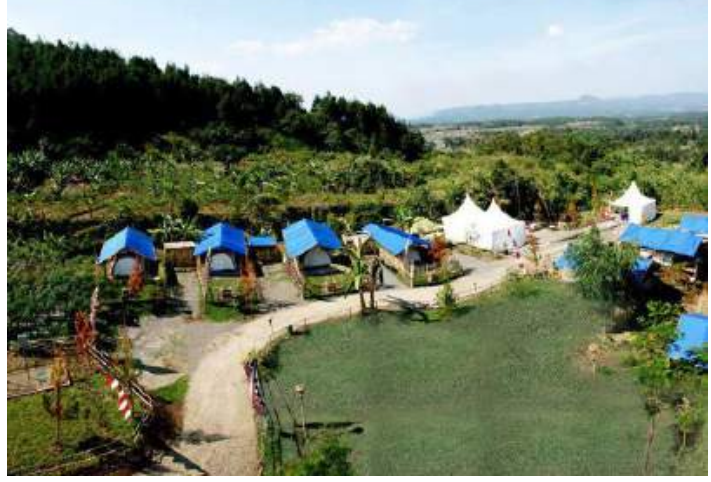

Gambar 1. Lokasi Camping Park Hotel X Sumber : Campany Profile, 2012

Melihat gambar 1, lokasi tersebut memiliki peluang atau potensi untuk dijual kepada pengunjung karena memiliki keindahan yang bisa dinikmati jauh dari kebisingan kota, sehingga pengunjung dapat rilex dengan pemandangan alamnya mendapatkan kesegaran udaranyanya, mndpatkan suasanaya, hijaunya taman dan bunyi air sungai, sehingga dibentuk konsep back to nature (wawancara dengan Samallo, tanggal 1 Oktober 2014).

\section{Perencanaan dan Progam PR Hotel X}

Perencanaan yang dilakukan oleh tim manajemen Hotel $X$ dalam membuat program camping park adalah mendesain produk yang berbeda dengan pesaing sehingga konsumen merasa nyaman. Perbedaan produk dengan pesaing pertama, jenis tenda yang digunakan sudah permanen, sementara pesain tenda didirikan sesuai pesanan dari pelanggan. Kedua, kualitas tenda yang berbeda dengan pesaing, tenda yang dimiliki oleh Hotel $\mathrm{X}$ memiliki bentuk dan ciri khas seperti layaknya kita tidur di kamar hotel. Seperti tenda dome berukuran sekitar $2 \times 5$ meter yang dilengkapi dengan beberapa tempat tidur dan selimut atau sleeping bag, siap menghangatkan Anda dan keluarga dari dinginnya udara kaki gunung Tangkuban Parahu. Tipe atau jenis tenda yang dipasarkan adalah sebagai berikut: 


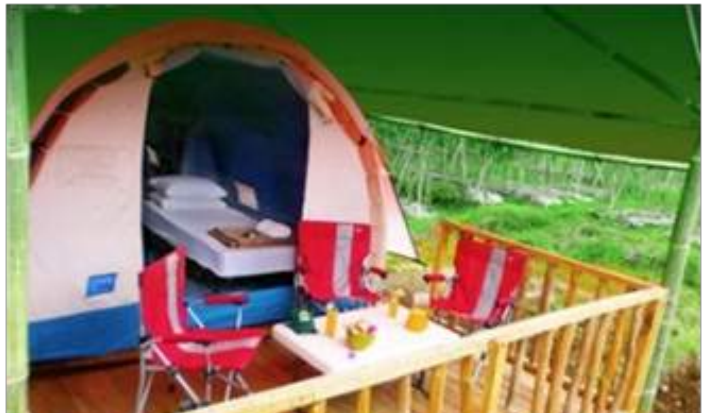

Gambar 2. Tipe Tenda

Tipe-tipe tenda tersebut ditawarkan kepada wisatawan, baik wisatawan domestic, nasional maupun internasional dan kepada para pelanggan tetap atau member card. Dari hasil wawancara yang dilakukan dengan Asst DOSM Hotel X bapak Hendra Wibawa mengemukakan bahwa perencanaan dilakukan melalui beberapa tahap sesuai dengan program kerja departemen marketing selama satu tahun, yaitu:

"Perencanaanjangka pendek yang dilakukan untuk mempromosikan camping park adalah dengan menyusun terlebih dahulu market segmennya. Segmentasi sasaran untuk memasarkan produk camping park, dilakukan berdasarkan segmentasi geografik, yaitu beradasarkan regional, nasional karena setiap wilayah memiliki karakter yang berbeda. Kemudian segmentasi demografik berdasarkan kelompok usia, dan segmentasi psikografik yang didasarkan pada status sosial dan gaya hidup konsumen serta segmentasi tingkah laku yang didasarkan pada tingkat pengetahuan dan sikap konsumen. Sosialisasi dilakukan kepada pengunjung yang sudah datang ke sari Ater, yang sedang datang ke Hotel X.... Perencanaan jangka menengah nya, pihak menajemen membuat suatu paket vacation package dalam bentuk penawaran tiga paket program rekreasi yaitu tea walk, lessure, sport game and adventure..... Perencanaan jangka panjang yang dilakukan adalah membuat pengembangan atau development dari area atau produk yang dimiliki camping park." (Dayang Sumbi, Minggu, 8 Juni 2014)

Perencanaan strategi yang digunakan dalam merancang komunikasi pemasaran, adalah perencanaan strategi operasional dan perencanaan strategi persuasi. Perencanaa strategi operasional melalui pendekatan kemasyarakatan melalui mekanisme sosial budaya dan mempertimbangkan nilai-nilai sosial yang berlaku agar produk ini bisa diterima oleh khalayak sekitar dan masyrakat umumnya. Selain strategi operasional, pihak manajemen menggunakan juga perencanaan strategi pendekatan persuasi dan edukatif dalam menyebarkan informasi kepada khalayak yang dijadikan sasaran. Program komunikasi pemasaran yang dilakukan oleh PR Manajer yang bekerjasama dengan bagian Sales marketing Manager melakukan kordinasi dalam hal penyusunan program promosi produk caming park baik secara langsung maupun tidak langsung, karena menurut PR Manager Hotel X

"kerjasama dari sisi promosinya dengan sales \& marketing manager. Jadi marketing masuk untuk brandingnya sementara PR masuk untuk publikasinya. Sehingga kordinasinya sangat erat antara PR dengan marketing, hanya beda peruntukannya." (Wawancara, 11 September, 2014).

Promosi produk camping park dilakukan secara langsung ditawarkan kepada para mengunjung atau wisatawan melalui komunikasi interpersonal dalam bentuk personal selling dengan menjelaskan secara langsung dan memberikan brosur atau leaflet. Langkah berikutnya membuat perencanaan sales promotion dengan mendatangi perusahaan-pusahaan atau departemendepartemen dengan cara memberikan surat penawaran dan melakukan presentasi produk. Secara tidak langsung membuat mempromosikan melalui media, baik media cetak maupun media elektronik dan media sosial (above the line) dan melakukan promosi melalui pameran-pameran, selebaran atau leaflet (below the line). Untuk mendukung suksesnya perencanaan program tersebut, melakukan penentuan personal yang terlibat yang memiliki kualifikasi atau 
skill yang sesuai dengan kemampuannya. Kemudian di susun rincian anggaran untuk biaya perencanaan program tersebut sehingga acara tersebut berjalan lancar dan sukses. Hal ini sesuai dengan hasil wawancara yang dikemukakan oleh PR Manager Hotel X bahwa;

"perencanaan program komunikasi pemasaran, salah satu dilakukan melalui penjualan personal dan sales promotion juga melalui pameran-pameran baik yang diselenggarakan oleh Pemerintah Pusat maupun Pemerintah Kabupaten, seperti Dinas Pariwisata Jawa Barat dan lembaga profesi, seperti PHRI." (Wawancara, 11 September, 2014).

\section{Mengambil Tindakan dan Komunikasi}

\section{Strategi Pemilihan Komunikator}

Setelah perencanaan tersusun dengan baik, maka langkah berikutnya adalah menyusun strategi komponen komunikasi yangdilakukanolehPRManagerbekerjasama dengan sales marketing manager Hotel $X$ karena menurut PR Manager Bapak Yuki Azuania mengemukakan bahwa;

"Antar PR dan marketing saling menunjang.PR merupakan komunikator terhadap media-media sepertimedia cetak maupun radio, sehingga tidak ada salah pemberian informasi. Menurut beliau, PR di bawah Divisi Sales dan Marketing, departemennya Sales Marketing, dulu PR membawahi marketing." (Wawancara, 10 September, 2014)

Jadi dalam menyusun strategi komunikasi untuk mempromosikan produk camping park, yang menjadi komunikator perusahaan Hotel $X$ adalah PR Manager

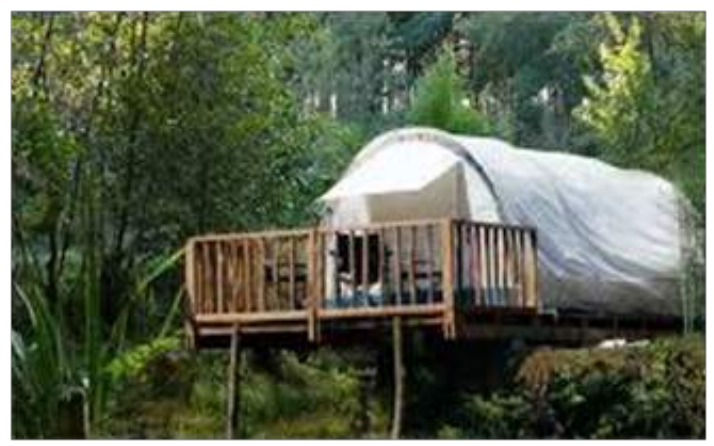

Gambar 3.Tipe Musang itu sendiri dan Sales Marketing Manager yang mewakili perusahaan Hotel $X$ untuk mendistribusikan pesan atau informasi produk camping park kepada publik yang dijadikan sasaran, baik public internal dan public eksternal. Karena menurut PR Manager public internal, yaitu para karyawan penting untuk mengetahui produk (product knowledge) baru yang dihasilkan perusahaan. Hal ini menurut PR Manager

"Seluruh karyawan Sari Ater adalah sebagai tenaga penjual, sehingga produk yang ada di Sari Ater dapat tersampaikan kepada pengunjung" (Wawancara, 10 September, 2014)

\section{Strategi Pemilihan Pesan}

Dalam menyusun pesan yang akan disampaikan ke public sasaran menggunakan bahasa yang mudah dimengerti dan dipahami oleh public. Bahasa yang digunakan adalah bahasa Indonesia dan Bahasa Inggris karena tamu yang datang atau wisatawan yang datang adalah wisatawan mancanegara, seperti Inggris, Saudi Arabia, Kanada, Jepang, Australia dan lain sebagainya. Pemilihan bahasa ini dirumuskan terlebih dahulu sebelum dikomunikasikan kepada public. Jadi bahasa tidak bukan menjadi masalah. Seperti yang dikemukakan oleh Manager Operasional bahwa:

"faktor bahasa tidak menjadi hambatan/ kendala bagi Hotel $X$, bahasa Indonsia dan bahasa Inggris menjadi bahasa yang dipakai untuk berkomunikasi dengan para

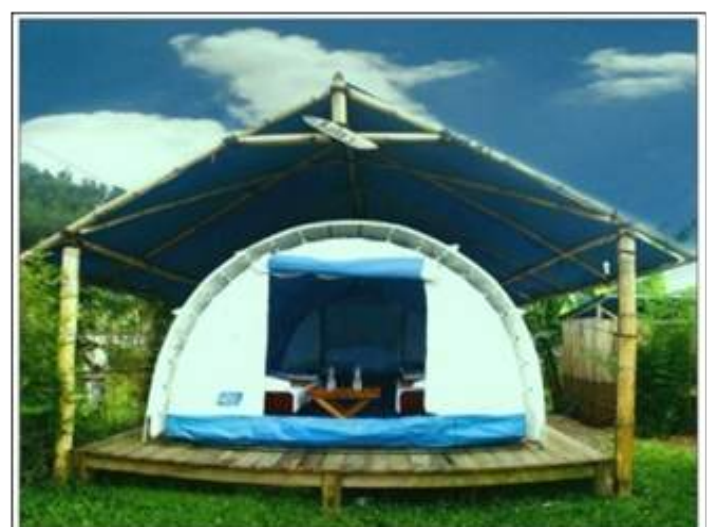

Gambar 4. Tipe Landak 
pengunjung walaupun banyak pengunjung yang datang tidak hanya berasal dalam negeri tetapi juga dari luar negeri."

\section{Strategi Pemilihan Media}

Penyusunan strategi pemilihan media atau saluran informasi yang digunakan oleh Hotel $\mathrm{X}$ didasarkan pada pertimbangan luasnya jangkauan media sehingga dapat diterima oleh public yang dijadikan sasaran. Dari hasil wawancara diperoleh informasi dari DSOM bahwa :

"Media informasi yang dilakukan dalam mempromosikan program-program yang ada di sari ater adalah menggunakan semua media, baik media konvensional maupun media digital. Brosur dan leaflet diberikan kepada pengunjung yang datang. Pameran yang diselenggarakan dalam memperkenal produk pada konsumen atau pengunjung. Kemudian, menggunakan media digital seperti Website atau internet juga dilakukan oleh PR dalam strategi pemilihan media promosi. Kerjasama dengan beberapa radio local seperti radio CBL, PRFM, KLCBS dan GSP dalam acara talk show juga dilakukan dalam mempromosikn produk-produk Sari Ater termsuk program camping park."

Hal senada dikemukakan oleh PR Manager Hotel X menyatakan bahwa

"PR sebagai pembuka jalan, melalui mediamedia,baik cetak dan elektronik dengan membuat press release, pameran-pameran, news letter yang berisikan inovatif dari produk Sari Ater. Facebook, website juga merupakan media promosi yang digunakan oleh Sari Ater.PR juga melakukan sosialisasi dengan penduduk sekitar area hotel mengenai keberadaan produk Sari Ater khususnya camping park."

Bentuk lainnya dari media yang digunakan adalah majalah dinding (madding) seperti yang dikemukakan Manager PR berikut ini, “Digunakan juga melalui penempatan madding, baik untuk informasi internal dan eksternal, yang berisi kegiatan-kegiatan yang telah dilakukan Sari Ater, foto-foto dari pengunjung (pejabat, perusahaan-perusahaan bahkan para celebrity) yang datang dan menginap di

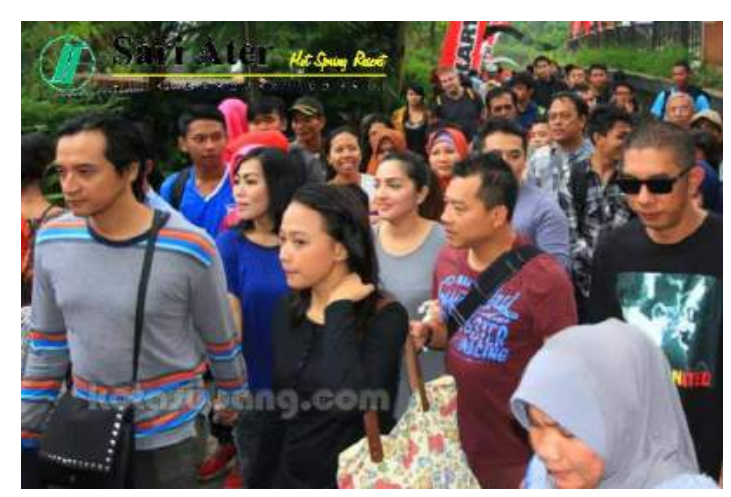

Gambar 5. Anang dan Ashanti sebagai tamu Hotel

Hotel X, seperti contoh foto kedatangan artis Anang dan Asanti yang menginap di camping park ini."

Jika kita simak hasil wawancara tersebut di atas, menggambarkan lingkup media yang digunakan oleh PR Manager Hotel X untuk mempromosikan produk camping park. Seperti above the line, yaitu media elektronik, seperti radio, tv dan surat kabar melalui press release dan membuat website, facebook di internet. Di samping itu, menggunakan below the line, seperti mempromosikan produk camping park melalui kegiatan pameran, membuat news letter dan memasang pengumuman dan majalah dinding agar dibaca oleh karyawan dan para pengunjung atau tamu yang datang menginap.

Startegi pemilihan media yang dilakukan oleh PR Manager Hotel X dapat dikatakan sudah tepat dalam mempromosikan produk camping sehingga dapat menimbulkan daya tarik bagi para pengunjung atau pun publik umumnya untuk datang mengunjungi Hotel X dan obyek rekreasi dilengkapi sarana yang memadai.

\section{Strategi pemilihan komunikan/Publik}

Untuk menentukan segmentasi sasaran atau target market, pihak manajemen Hotel $\mathrm{X}$ menentukan segmentasinya middle up yaitu menengah ke atas yaitu perusahaan atau kelompok atau keluarga karena sesuai dengan produk camping park. 


\section{Strategi Pemilihan Efek}

Efek yang diharapkan dari kegiatan promosi camping park adalah memperoleh posisi (posisioning) produk dimata pengungjung atau wisatawan yang datang untuk menginap. Selain memperoleh posisi maka akan terwujud citra produk (brand image product) di mata pengunjung. $P R$ menjadi jembatan antara manajemen dengan warga masyarakat.PR juga sebagai sales yang dapat menghasilkan keuntungan bagi perusahaan dan memperoleh posisi dan citra perusahaan dimata public

\section{Mengevaluasi Program.}

Langkah terakhir dalam proses ini adalah melakukan penilaian atas persiapan, implementasi dan hasil dari program. Penyesuaian akan dilakukan sembari program diimplementasikan dan didasarkan pada evaluasi atas umpan balik tentang bagaimana program itu berhasil atau tidak. Evaluasi program yang dilakukan oleh Manager PR Hotel $\mathrm{X}$ adalah dengan cara menyediakan guest comment yang disediakan di setiap tenda yang ada di camping park, dari hasil guest comment tersebut, pihak manajemen Hotel $X$ dapat mengetahui seberapa besar tingkat keberhasilan dari program vacation package atau special discount dari para pengunjung atau wisatawan yang menginap di Hotel $X$. Jika hasil guest comment itu pengunjung merasa puas dengan fasilitas dan pelayanan yang diberikan Hotel $\mathrm{X}$, maka langkah selanjutnya yang dilakukan oleh PR adalah mempertahankan dan meningkat posisi produk tersebut agar dapat membentuk citra. Kemudian, jika hasilnya kurang, pihak Hotel $X$ akan memperbaiki kekurangan tersebut untuk lebih memperhatikan keluhan-keluhan yang masuk, seperti yang dikemuakakan DSOM bahwa

\footnotetext{
"Guest comment dari para pengunjung juga menjadikan motivasi bagi pihak manajemen Sari Ater untuk terus meningkatkan mutu dan pelayanan kepada pengunjung." (Wawancara, 1-10-2014)
}

Berdasarkan penilaian yang dilakukan oleh pengunjung tersebut menunjukkan bahwa produk camping park telah memiliki posisi atau penilaian tersendiri, pada gilirannya sudah membentuk citra produk. Salah satu penilaian atau komentar terhadap posisi camping park dikemukaan oleh beberapa pengunjung yang menyatakan:

"Terimakasih buat suluruh tim sari Ater Hotel, suasana camping park sangat bagus karena letaknya yang dikelilingi gunung di dekat sungai, menambah pemandangan yang alami serta sarana dan fasilitas nya sangat lengkap ditambah tayangan yang memuaskan, membuat kami bisa menyelenggarakan acara family gathering dengan lancar dan sukses. Hasil wawancara dengan Naizar, Realty T\&T pada tanggal 9 Maret 2014) kemudian keluarga H. Deni dari Kalimantan mengatakan pelayanan manajemen camping park sudah bagus, agar ditingkatkan lagi." Wawancara tanggal 30 Juli 2014

Untuk mempertahankan agar posisi produk yang sudah terbentuk citranya, pihak PR manager Hotel $X$ melakukan human relations dengan pelanggan atau tamu yang pernah datang, seperti yang dikemukakan berikut ini.

"Strategi komuniksi lain yang dilakukan oleh PR secara rutin adalah menjadwalkan kunjungan ke media dan menjalin komunikasi terus menerus melalui telepon kepada tamu potensial yang pernah berkunjung dan menginap khususnya do camping park Sari Ater."

Strategi komunikasi lain yang digunakan oleh PR Manager adalah melalui pendekatan persuasi dan komunikasi interpersonal adalah

“Mengadakan key person invitation dengan mengundang General Manager hotel-hotel berbintang, para duta besar, bahkan para menteri yang diberikan member card secara gratis. Selain itu komunikasi yang dilakukan dengan mengirimkan news letter kepada para kolega agar mereka mengetahui bukan hanya ada makanan tapi juga ada program outbound, juga tips-tips kesehatan apabila mereka menggunakan air panas yang menjadi ciri khas di Sari Ater." 


\section{Simpulan}

Berdasarkan hasil penelitian dan pembahasan serta interpretasi data sebagaimana yang telah diuraikan, maka dapat ditarik kesimpulan sebagai berikut; 1) Tahap pertama yang dilakukan oleh PR Manager Hotel X sebelum membangun camping park adalah mendefinisikan masalah terlebih dahulu melalui survey dan observasi kepada pesaing yang telah terlebih dahulu memiliki produk perkemahan dan kepada komunitas atau lingkungan sekitar yang berada di wilayah Hotel $\mathrm{X}$ tujuannya adalah untuk mendesain produk yang berbeda dengan pesaing, 2) Tahap kedua adalah perencanaan program dilakukan melalui jangka pendek, jangka menengah dan jangka panjang serta membuat program vacation package dan special discount untuk pengunjung, 3) Tahap ketiga mengambil tindakan dan komunikasi dengan cara menentukan strategi komunikasi melalui komponen komunikasi, seperti menentukan strategi pemilihan komunikator, strategi pemilihan pesan, strategi pemilihan khalayak/ komunikan dan strategi pemilihan efek dengan mempertimbangkan keinginan dan kebutuhan para pengunjung atau wisatawan yang datang menginap di camping park, 4) Tahap keempat adalah Mengevaluasi semua program yang dilakukan oleh PR Manager Hotel X yang bekerjasama dengan DSOM melalui guest comment yang diberikan oleh pengunjung untuk kemudian komentar atau penilaian dari pengunjung didiskusikan dan ditindak lanjuti sesuai dengan saran atau masukan yang diterima. Hasil dari komentar pengunjung dinilai baik dan posisi produk sudah terbentuk citranya.

\section{Daftar Pustaka}

Jefkins, Frank. Public Relations, Edisi Ke Lima diterjemahkan oleh Daniel Yadin. Jakarta: Erlangga.

Kotler, Philip, Gary Amstrong. . Principles of Marketing. New York: Prentice Hall; Ed 5.

Milles, M.B. and Huberman, (1984). Qualitative Data Analysis. London: Sage Publication.

Ruliana, Poppy. (2014). Komunikasi Organisasi, Teori dan Studi Kasus. Jakarta: Raja Grafindo.

Sugiyono. (2008). Memahami Penelitian Kualitatif, Bandung: Alfabeta.

Sulaksana, Uyung. (2003). Integrated Marketing Communications, Yogyakarta, Pustaka Pelajar Offset.

Sutisna. (2001). Perilaku Konsumen dan Komunikasi Perusahaan, Bandung, PT. Remaja Rosdakarya.

Yoeti, Oka A.. (1999). Strategi Pemasaran Hotel. Bandung: PT. Gramedia Pustaka Utama.

\section{Sumber lain :}

Company Profile Hotel X 2012 - Proses Perencanaan IMC.[1]. Diakses 5 Mei 2010 http://aryaajus.blogspot. com/2009/01/segmentasi-pasartarget-pasar-dan.html

tgif-consulting.blogspot.com/.../pentingnyapositioning

id.wikipedia.org/wiki/Komunikasi_ pemasaran_terpadu

http://tourismbali.wordpress.com/2012/02/10/ komunikasi-pemasaran-pariwisata-danperhotelan

http:/ / www.sarjanaku.com/2013/03/ pengertin -komunikasi-pemasaran-ht 